\title{
Pendampingan Identifikasi Potensi Pengembangan Agrowisata Berbasis Partisipasi Masyarakat di Desa Tirtomulyo, Kretek, Bantul, Yogyakarta
}

\section{(Community Assistance to Identify the Potential of Community Participation-Based Agro-tourism Development in Tirtomulyo Village, Kretek, Bantul, Yogyakarta)}

\author{
Siti Nurul Rofiqo Irwan ${ }^{1 *}$, Hani Perwitasari ${ }^{2}$, Muhamad Muhamad ${ }^{3}$ \\ 1 Departemen Budidaya Pertanian, Fakultas Pertanian, Universitas Gadjah Mada, JL. Flora, Bulaksumur, Caturtunggal, \\ Depok, Sleman, Yogyakarta 55281. \\ 2 Departemen Sosial Ekonomi Pertanian, Fakultas Pertanian, Universitas Gadjah Mada, JL. Flora, Bulaksumur, Caturtunggal, \\ Depok, Sleman, Yogyakarta 55281. \\ ${ }^{3}$ Magister Kajian Pariwisata, Sekolah Pascasarjana, Universitas Gadjah Mada, Bulaksumur, Caturtunggal, Depok, Sleman, \\ Yogyakarta 55281 \\ *Penulis Korespondensi: rofiqoirwan@ugm.ac.id \\ Diterima November 2020/Disetujui May 2021
}

\begin{abstract}
ABSTRAK
Desa Tirtomulyo terletak di jalur wisata Pantai Parangtritis Kabupaten Bantul. Pantai Parangtritis adalah salah satu destinasi wisata utama di Daerah Istimewa Yogyakarta. Desa Tritomuyo memiliki potensi untuk berkembang menjadi kawasan agrowisata berdasarkan potensi sumber daya alam dan partisipasi masyarakat. Melalui program Desa Binaan Universitas Gadjah Mada dilakukan pengembangan agrowisata berbasis masyarakat. Program ini bertujuan 1) Mengidentifikasi potensi sumber daya alam dan lanskap desa; 2) Meningkatkan partisipasi masyarakat untuk membangun desa; dan 3) Memberdayakan sumber daya alam dan masyarakat desa untuk pengembangan agrowisata. Metode pelaksanaan berbasis potensi desa dan masyarakat yaitu modifikasi penilaian pedesaan secara cepat dan penilaian pedesaan secara partisipatif. Perencanaan agrowisata berbasis partisipasi masyarakat menggunakan metode Business Model Canvas (BMC) dan sistem Training on trainer. Program dilaksanakan Juni-Oktober 2020. Metode edukasi dan pelaksanaan menyesuaikan situasi di masa pandemi Covid 19, yaitu menggunakan metode dalam jaringan (online) dengan platform google meet dan whatsapp group. Pelaksanaan program pertemuan langsung (offline) dilakukan secara terbatas dengan protokol kesehatan. Identifikasi potensi yang dilakukan oleh masyarakat di 15 pedukuhan Desa Tirtomulyo menunjukkan potensi atraksi sumber daya alam berbasis kearifan lokal terdiri dari pemandangan alam, pekarangan, seni tari, kerajinan tangan, kuliner, dan perikanan. Diskusi secara online dan offline serta pembuatan poster BMC menunjukkan upaya masyarakat berpartisipasi dalam membangun desa untuk pengembangan agrowisata. Berbagai sumber daya alam sebagai potensi atraksi agrowisata sudah mulai diberdayakan di antaranya pembibitan tanaman di pekarangan, rempeyek, gula semut dan kripik bonggol pisang, homestay. Namun koordinasi program agrowisata antar dusun di tingkat desa masih perlu ditingkatkan.
\end{abstract}

Kata kunci: agrowisata, Bantul, desa Tirtomulyo, partisipasi masyarakat, Yogyakarta.

\begin{abstract}
Tirtomulyo Village is located enroute the Parangtritis Beach, which is one of the main tourist destinations in the Bantul Region of Yogyakarta. This village has the potential to develop into an agro-tourism area based on the natural resources and community participation. Presently, community-based agro-tourism is being developed in this area through the Gadjah Mada University Assisted Village program. Therefore, this programme aims to 1) Identify the potential of natural resources and village landscapes; 2) Increase community participation in developing villages; and 3) Empower natural resources and village communities for agro-tourism development. Data were obtained from community participation-based agro-tourism planning using the Business Model Canvas (BMC) method and the Training on Trainer system from June to October 2020. Furthermore, during the Covid 19 pandemic, tourism education was carried out using an online method such as Google meet and whatsapp group platforms. The implementation of the direct meeting program (offline) was limited due to health protocol. Potential identification carried out by the community in 15 hamlets of Tirtomulyo Village shows the potential for natural resource attractions based on local wisdom consisting of natural resources, yards (pekarangan), cultural table 1dance, handicrafts, culinary, and fisheries. The result showed that online and offline discussions and the making of BMC posters are some of the efforts used in building villages for agro-
\end{abstract}


tourism development. Furthermore, various natural resources as the potential of agro-tourism attractions have started to be empowered, including plant nurseries in the yard (pekarangan), peanut brittle, gula semut, and banana weevil chips well as a homestay. Therefore, the coordination of the inter-hamlet agro-tourism program at the village level still needs to be improved.

Keywords: agro-tourism, Bantul, community participation, Tirtomulyo village, Yogyakarta

\section{PENDAHULUAN}

Desa Tirtomulyo merupakan salah satu dari 5 desa yang ada di Kecamatan Kretek, Kabupaten Bantul, Provinsi Daerah Istimewa Yogyakarta. Luas wilayah Desa Tirtomulyo 418.730 ha dan jumlah penduduk 7752 jiwa. Berdasarkan letaknya Desa Tirtomulyo sangat berpotensi menjadi daerah kunjungan wisata di daerah Bantul, Yogyakarta karena berada di jalur wisata Kota Yogyakarta dan Pantai Parangtritis, Kabupaten Bantul, Daerah Istimewa Yogyakarta.

Nama Desa Tirtomulyo terdiri dari kata tirto (air) dan mulyo (melimpah). Desa ini memiliki sumber daya dari 15 pedukuhan, yaitu Pedukuhan Plesan, Paliyan, Karen, Gondangan, Kergan, Bracan, Tokolan, Tluren, Gaten, Jebugan, Karangweru, Genting, Soropadan, Jetis, dan Punduhan. Sebagian dusun/dukuh ini sudah mengembangkan sumber daya alamnya menjadi atraksi wisata pertanian atau agrowisata berdasarkan kearifan lokal dan partisipasi masyarakat, namun belum ada koordinasi dan integrasi di tingkat desa. Agrowisata di tingkat desa diharapkan dapat dikembangkan sehingga Desa Tirtomulyo dapat menjadi destinasi wisata di daerah jalur wisata Pantai Prangtritis Yogyakarta.

Agrowisata merupakan destinasi wisata dengan objek dan daya tarik lahan pertanian atau yang terkait dengan pertanian (Putra et al. 2018). Umumnya lahan desa didominasi lahan pertanian baik pekarangan maupun kebun, sehingga bentuk wisata desa potensial dikembangkan adalah wisata pertanian atau agrowisata. Agrowisata merupakan sumber pendapatan petani dan dapat meningkatkan perekonomian desa (Budiarti et al. 2013; Irwan et al. 2018). Agrowisata di Kabupaten Bantul sudah banyak dirintis oleh desa lainnya. Irwan et al. (2018) menyatakan pekarangan di Desa Mangunan, Bantul, Yogyakarta dapat menjadi atraksi agrowisata melalui pengembangan lanskap produktif. Agrowisata merupakan bentuk pemberdayaan sumber daya alam, lanskap dan masyarakat desa yang potensial untuk meningkatkan perekonomian masyarakat di desa tersebut. Pengelolaaan atraksi wisata harus terintegrasi di setiap dusun disertakan dengan fasilitas dan pemanduan wisata sehingga dapat mengoptimalkan kunjungan wisata antar dusun. Agrowisata dapat menjadi wisata edukasi bagi seluruh sekmen masyarakat sambil melakukan aktivitas rekreasi (Aristya et al. 2017; Irwan et al. 2019).

Pemberdayaan sumber daya alam dan partisipasi masyarakat belum optimal di Desa Tirtomulyo. Jumlah dan kualitas sumber daya manusia sangat penting dalam pengembangan kawasan pariwisata sehingga dapat bersaing dan berkelanjutan (Budi 2015). Oleh karena itu, diperlukan pembinaan dan pendampingan secara berkelanjutan melalui program Desa Binaan Universitas Gadjah Mada tahun 2020, dilakukan pendampingan yang bertujuan 1) Mengidentifikasi potensi sumber daya alam desa, 2) Meningkatkan partisipasi masyarakat untuk membangun desa; 3) Memberdayakan sumber daya alam dan masyarakat desa untuk pengembangan agrowisata. Desa ini diharapkan dapat menjadi destinasi agrowisata melalui kemandirian masyarakat pada beberapa tahun ke depan. Kemandirian masyarakat dalam identifikasi masalah dan potensi sangat penting untuk penyusunan program kerja dan perencanaan agrowisata sehingga dapat diupayakan terealisasi (Tamam et al. 2020). Dalam program inovasi sosial (social innovation), pengelola agrowisata dan mitra pengelola mengembangkan kegiatan wisata, yaitu aktivitas pertanian dan pariwisata berkelanjutan melalui program jasa ekosistem (ecosystem services). Lahan pertanian tidak hanya sebagai atraksi agrowisata tetapi juga bagian dan pengelolaan wisata secara keseluruhan dan berkelanjutan (Batle et al. 2018).

\section{METODE PELAKSANAAN}

\section{Waktu dan Tempat}

Kegiatan Pengabdian kepada masyarakat berbasis Desa Binaan Univeristas Gadjah Mada ini dilaksanakan pada bulan Juni-Oktober 2020 di Desa Tirtomulyo, Kecamatan Kretek, Kabupaten Bantul, Provinsi Daerah Istimewa Yogyakarta (Gambar 1). Desa Tirtomulyo berada di jalur 


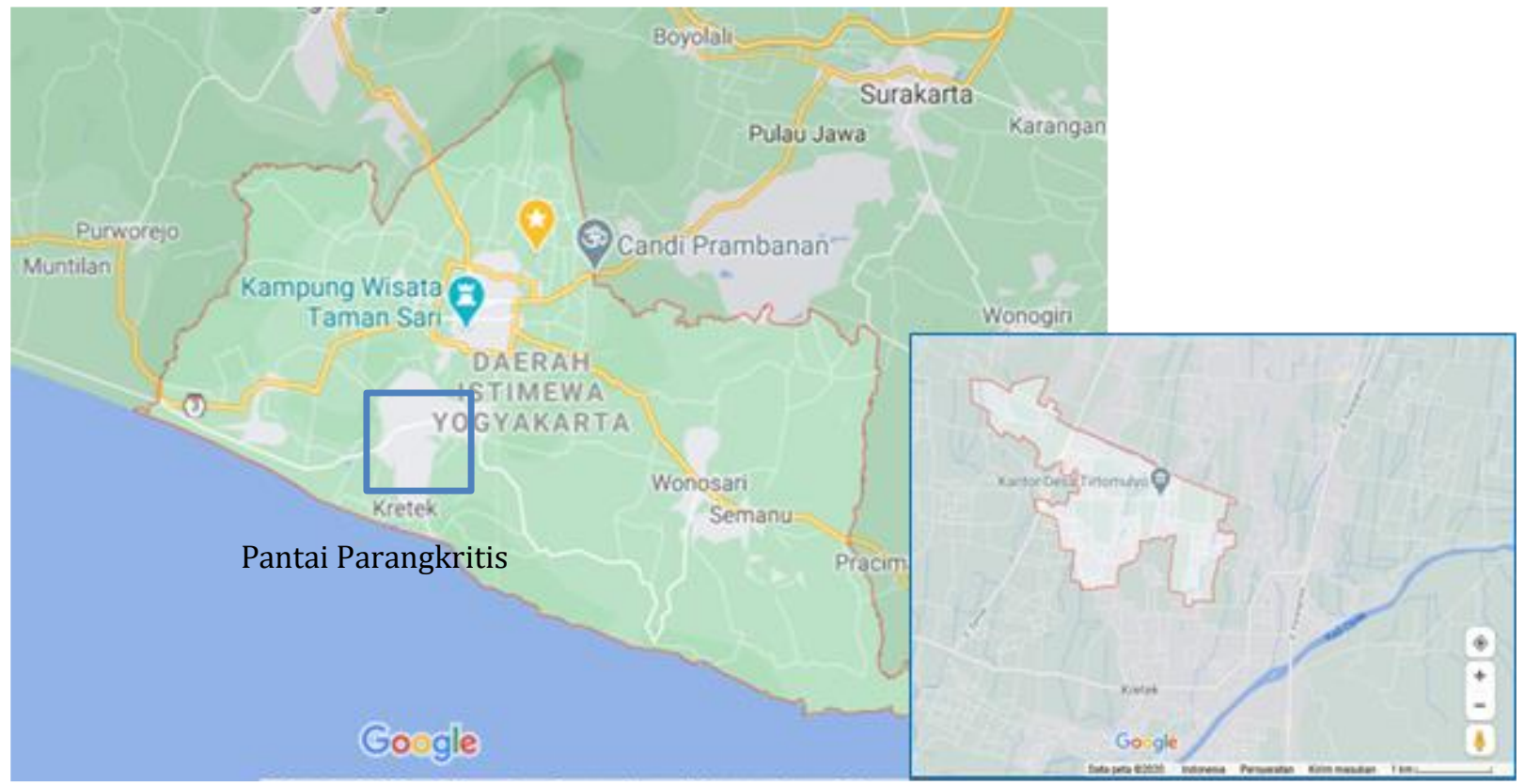

Sumber: maps.google.com (2020)

Gambar 1 Lokasi Desa Tirtomulyo, Kecamatan Kretek, Kabupaten Bantul, Daerah Istimewa Yogyakarta.

wisata menuju Kawasan Pantai Parangtritis. Desa ini terletak sekitar $8 \mathrm{~km}$ di Utara Pantai Parangtritis dan $27 \mathrm{~km}$ di selatan pusat Kota Yogyakarta.

\section{Metode Pengambilan Data}

Metode pelaksanaan disesuaikan dengan situasi pandemi Covid 19 tahun 2020. Penyuluhan dilakukan secara daring atau online melalui ruang meeting virtual, google meet, sebanyak empat kali di bulan Juli dan Oktober 2020. Diskusi online dilanjutkan dengan diskusi melalui whatapps group. Pertemuan langsung dengan masyarakat (offline) juga dilakukan secara terbatas dan dengan protokol kesehatan ketat, yaitu memakai masker, mencuci tangan, dan menjaga jarak (3M). Metode pengumpulan data dan pelaksanaan dilakukan melalui modifikasi penilaian pedesaan secara cepat (rapid rural appraisal) dan penilaian pedesaan melalui partisipasi masyarakat (participatory rural appraisal) (Lara et al. 2018). Perencanaan agrowisata berbasis partisipasi masyarakat menggunakan metode Business Model Canvas (BMC) (Salvador et al. 2021) dan sistem Training on Trainer (TOT). Poster BMC bertujuan mempermudah presentasi model bisnis secara detil, jelas, dan mudah dipahami. Metode BMC biasa digunakan para manajer dan pengusaha untuk merencanakan dan membuat program bisnisnya (Keane et al. 2018).

Sistem TOT digunakan untuk melatih masyarakat secara berkelanjutan dan berkelompok.
Setiap dusun membentuk kelompok kerja untuk mengidentifikasi potensi dusun masing-masing. Dari 15 dusun di Tirtomulyo dipilih tiga dusun penggerak berdasar presentasi terbaik pada acara Sarasehan Desa. Tiga dusun tersebut menjadi koordinator desa atau pelatih dusun lainnya untuk mengembangkan agrowisata di tingkat desa. Sisa 12 dusun dibagi tiga kelompok, masing-masing kelompok terdiri empat dusun. Metode pengumpulan data dan pelaksanaan menggunakan kombinasi beberapa cara, yaitu 1) Survei dan kajian pustaka; 2) Focus Group Discussion (FGD); 3) Penyuluhan daring; 4) Kuesioner online menggunakan google form; 5) Presentasi oleh masyarakat di acara Sarasehan Desa; dan 6) Perencanaan bersama masyarakat. Gambar 2 menunjukkan skema perencanaan yang dilaksanakan di Desa Tirtomulyo.

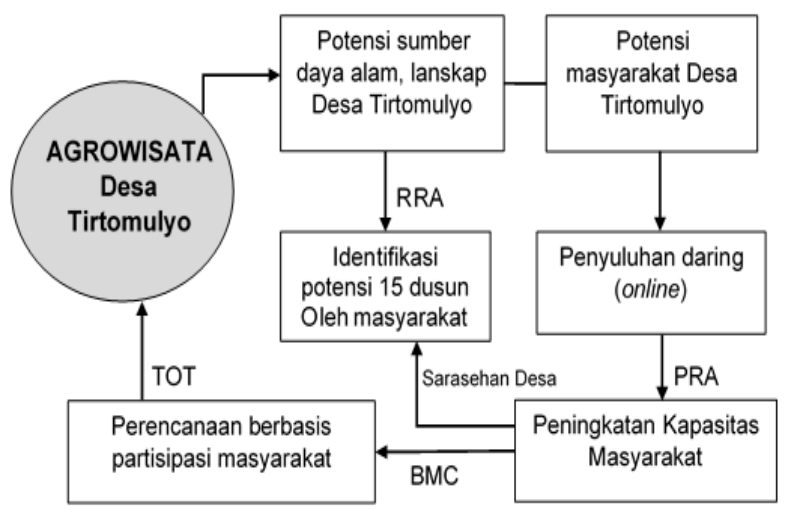

Gambar 2 Skema perencanaan agrowisata berbasis masyarakat di Desa Tirtomulyo. 


\section{HASIL DAN PEMBAHASAN}

Kegiatan pengembangan wisata desa berbasis agrowisata dimulai dengan survei identitas potensi desa yang dilakukan oleh masyarakat. Identifikasi potensi atraksi wisata dipresentasikan oleh 15 dusun dengan menillai secara spontan dan cepat mengenai keunggulan, kecenderungan minat dan kemenarikan objek. Minat terhadap objek ditandai dengan penjualan produk secara langsung, kunjungan ke desa dan pemesanan produk. Potensi atraksi Desa Tirtomulyo dari 15 dusun dapat diklasifikasikan berupa pekarangan, pertanian kebun, perikanan, produk pangan, kuliner, seni budaya, dan kerajinan tangan (Tabel 1). Untuk perikanan lebih banyak budi daya ikan lele, kecuali Dusun Kergan dengan budi daya ikan gurame. Tabel potensi atraksi agrowisata menunjukkan pekarangan merupakan potensi tertinggi sebagai atraksi utama agrowisata. Selanjutnya terdapat atraksi pendukung agrowisata seperti kuliner, seni budaya, kerajinan tangan dan homestay.

Beberapa produk pangan di Desa Tirtomulyo sudah ada namun perlu dipromosikan sebagai bagian dari potensi atraksi wisata, yaitu rempeyek, gula semut, dan kripik bonggol serta bentuk kuliner lainnya sebagai atraksi utama (Gambar 3). Atraksi pendukung agrowisata terdiri dari kerajinan tangan, seni tari Reog, dan fasilitas homestay sebagai fasilitas wisata (Gambar 4). Lahan pekarangan menjadi perhatian khusus masyarakat Desa Tirtomulyo untuk dikembangkan dan ditingkatkan daya tariknya menjadi ikon desa. Perhatian terhadap pengembangan wisata desa ini terinspirasi oleh pengembangan wisata serupa di Bangkok Thailand (Gambar 5) di mana pekarangan menjadi atraksi yang dikunjungi. Atraksi pekarangan ini diikuti dengan atraksi kuliner dan kerajinan tangan. Atraksi wisata yang diperlukan pada jaman milenial ini di antaranya adalah atraksi

Tabel 1 Potensi atraksi agrowisata di Desa Tirtomulyo

\begin{tabular}{|c|c|c|c|c|c|c|c|}
\hline $\begin{array}{c}\text { Dusun } \\
\text { (pedukuhan) }\end{array}$ & Pekarangan** & Pertanian** & Perikanan** & $\begin{array}{c}\text { Pangan } \\
\text { dan } \\
\text { kuliner** }\end{array}$ & $\begin{array}{c}\text { Seni } \\
\text { budaya* }\end{array}$ & $\begin{array}{c}\text { Kerajinan } \\
\text { tangan* }\end{array}$ & Homestay* \\
\hline Plesan & & & & & $\sqrt{ }$ & & \\
\hline Paliyan & $\sqrt{ }$ & $\sqrt{ }$ & & $\sqrt{ }$ & & & \\
\hline Karen & $\sqrt{ }$ & & & & $\sqrt{ }$ & & \\
\hline Gondangan & & & $\sqrt{ }$ & & & & \\
\hline Kergan & & & $\sqrt{ }$ & & & & \\
\hline Bracan & $\sqrt{ }$ & & $\sqrt{ }$ & & & & \\
\hline Tokolan & $\sqrt{ }$ & & $\sqrt{ }$ & & & & \\
\hline Tluren & & $\sqrt{ }$ & & $\sqrt{ }$ & & $\sqrt{ }$ & \\
\hline $\begin{array}{c}\text { Gaten } \\
\text { Jebugan }\end{array}$ & $\sqrt{ }$ & $\sqrt{ }$ & & $\begin{array}{l}\sqrt{ } \\
\sqrt{ }\end{array}$ & & & \\
\hline Karangweru & & $\sqrt{ }$ & & $\sqrt{ }$ & $\sqrt{ }$ & & \\
\hline Genting & $\sqrt{ }$ & $\sqrt{ }$ & & & $\sqrt{ }$ & & \\
\hline Soropadan & & & & $\sqrt{ }$ & & & $\sqrt{ }$ \\
\hline $\begin{array}{c}\text { Jetis } \\
\text { Punduhan }\end{array}$ & $\sqrt{ }$ & $\sqrt{ }$ & $\sqrt{ }$ & & & & \\
\hline
\end{tabular}

Keterangan: * atraksi utama, ** atraksi pendukung agrowisata Desa Tirtomulyo

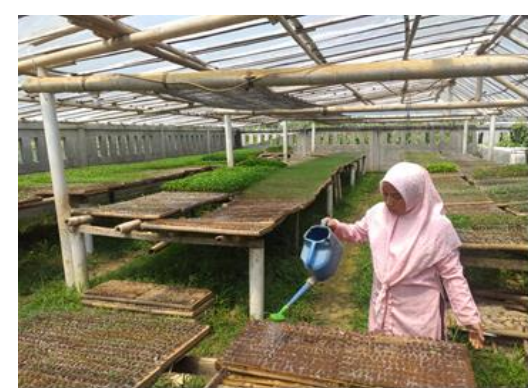

a

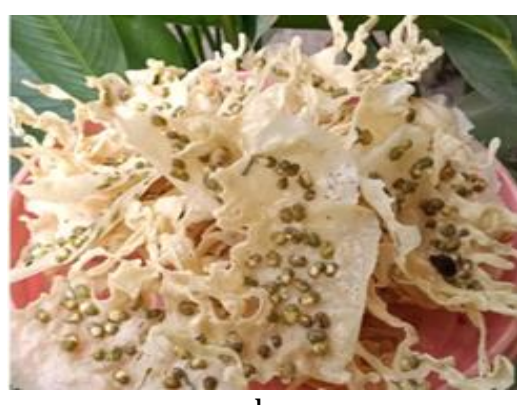

b

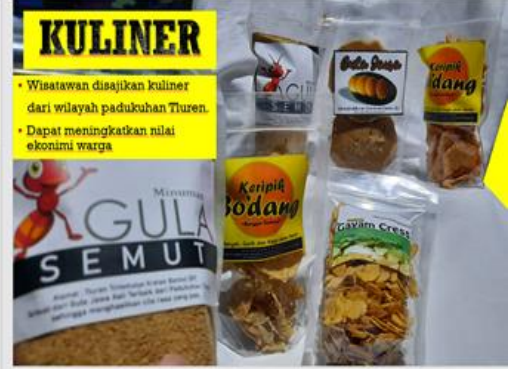

c

Sumber: Dokumentasi pribadi masyarakat Tirtomulyo (2020)

Gambar 3 a) Pekarangan; b) Rempeyek; dan c) Gula semut dan kripik bonggol pisang sebagai atraksi utama agrowisata. 


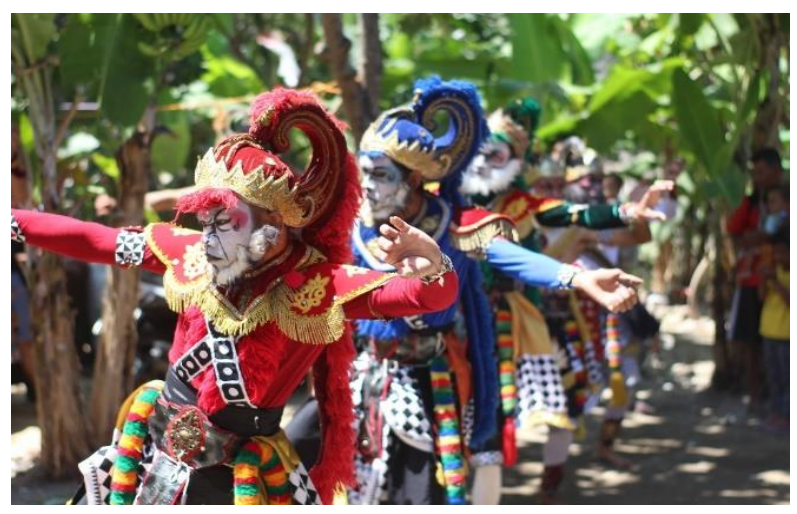

a

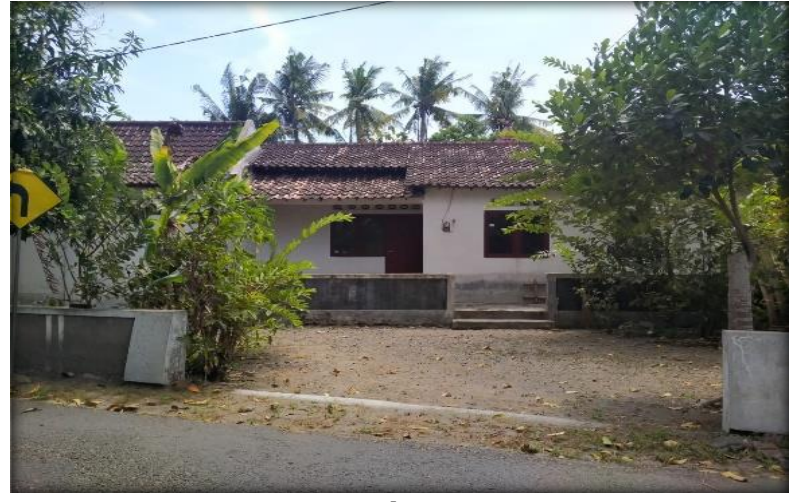

b

Sumber: Dokumentasi pribadi masyarakat Tirtomulyo (2020)

Gambar 4 a) Seni tari Reog Wayang menjadi atraksi pendukung agrowisata dan b) Fasilitas homestay.

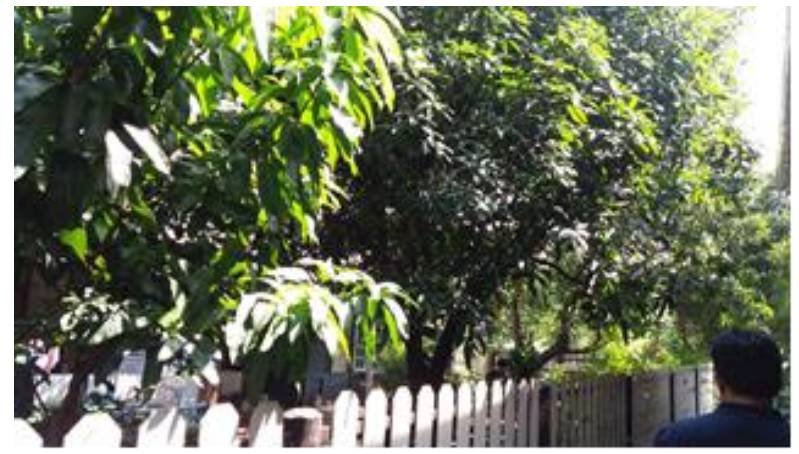

a

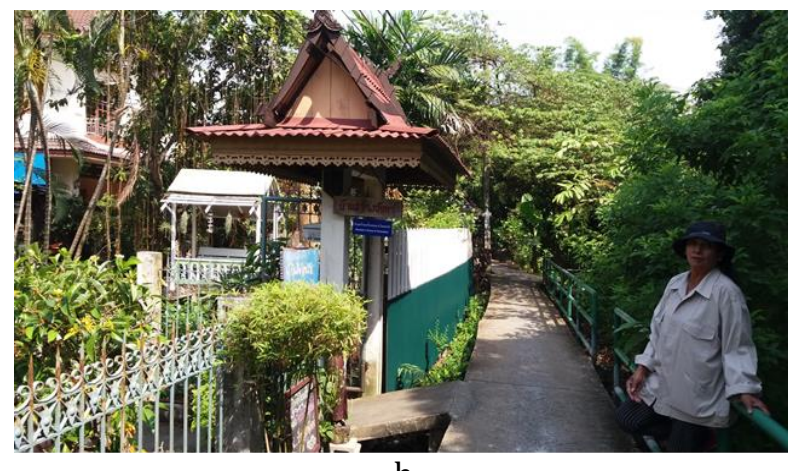

b

Sumber: dokumentasi pribadi (2018)

Gambar 5 a dan b Pekarangan sebagai atraksi wisata di Kota Bangkok Thailand.

yang sesuai untuk tampil di media sosial, seperti facebook dan instagram karena adanya objek dan daya tarik yang instagramable. Oleh karena itu pengemasan potensi atraksi wisata desa perlu mengarah kepada tren kekinian khususnya di kalangan generasi muda.

Desa Tirmomulyo mengupayakan pengembangan agrowisata berbasis masyarakat (community based agro-tourism) memerlukan strategi dalam pengembangan, yaitu memanfaatkan lahan pertanian di antaranya pekarangan sebagai potensi atraksi agrowisata. Selanjutnya diperlukan pendampingan masyarakat untuk merumuskan program kerja dalam perencanaan. Jika atraksi agrowisata sudah disiapkan sesuai dengan potensi desa, atraksi tersebut perlu dipromosikan sebagai destinasi agrowisata. Prioritas berikutnya adalah membuat brand agrowisata yang selalu diperbaharui produknya melalui keterlibatan masyarakat secara berkelanjutan (Putra et al. 2018). Pendampingan pengembangan atraksi wisata menjadi objek dan daya tarik wisata dapat berbasis pada kebudayaan, kreativitas, dan kesenian di desa (Wisesa et al. 2018). Kuliner berpotensi tinggi menjadi atraksi wisata. Motivasi pengunjung untuk berwisata kuliner memberi dampak positif pada sosial budaya dan perekonomian desa (Wondirad et al. 2021). Sebagai contoh desa wisata di Kutuarjo Jawa Tengah, pemandangan alam dan kuliner dimanfaatkan masyarakat sebagai atraksi agrowsaita sehingga dapat mendorong kegiatan ekonomi, meningkatkan penghasilan, dan kualitas hunian masyarakat. Sebelumnya desa ini berada pada situasi kumuh, pembuangan sampah tidak terkelola baik, dan sistem pembuangan air tidak teratur. Berkat partisipasi masyarakat desa ini dapat berkembang menjadi destinasi agrowisata (Sesotyaningtyas \& Manaf 2015).

Berdasarkan survei pada 50 responden masyarakat tentang kepemilikan pekarangan, diketahui seluruh masyarakat memiliki pekarangan. Sekitar 26\% memiliki kategori pekarangan sedang hingga luas (120-1000 $\left.\mathrm{m}^{2}\right)$. Pekarangan dengan luas di bawah $120 \mathrm{~m}^{2}$ yang dimiliki $66 \%$ responden menunjukkan adanya potensi untuk dikembangkan menjadi atraksi agrowisata. Selain itu masih ada empat rumah kategori pekarangan sangat luas di atas $1000 \mathrm{~m}^{2}$ 
(Gambar 6). Pengembangan pekarangan dapat dikelola mulai dari budi daya tanaman atau pertanaman (on farm) hingga ke produk olahan pertanian yang dapat menjadi kuliner dan buah tangan wisatawan. Tabel 2 dan 3 menunjukkan masyarakat aktif memanfaatkan pekarangan dengan membudidayakan berbagai jenis tanaman di antaranya sayuran, herbal, dan tanaman buah serta menyediakan elemen pekarangan seperti kolam ikan, gazebo, dan bangku taman. Tanaman buah dan kolam ikan merupakan jumlah terbanyak, yaitu 46,81 dan 48,28\%. Hal ini menjadi potensi yang dapat menambah daya tarik pekarangan dan memberi motivasi bagi masyarakat dalam mengembangkan berbagai aktivitas pemanfaatan pekarangan sebagai atraksi agrowisata sebagaimana diinspirasikan pada Gambar 5. Studi di Eropa menunjukkan lanskap pertanian memiliki nilai alam dan budaya tinggi yang rentan hilang jika tidak diberdayakan. Program ekowisata, pendidikan, dan warisan budaya pada pengembangan ekowisata diperlukan dengan memanfaatkan potensi alam dan budaya tersebut (Balázsi et al. 2021).

Pemberdayaan masyarakat di Desa Tirtomulyo diawali dengan memberikan penyuluhan online secara berkesinambungan. Pada masa pandemi Covid 19 tahun 2020 ini penyuluhan dilakukan secara daring (online) sebanyak empat kali dengan materi identifikasi potensi dan masalah desa. Peserta penyuluhan yang diharapkan adalah dua orang perwakilan setiap dusun dan perwakilan pamong desa, sehingga dari 15 dusun diharapkan peserta penyuluhan minimal sebanyak 30 peserta. Kehadiran penyuluhan online pertama hanya 7 orang atau $23,3 \%$, masih jauh dari target. Hal ini diduga masyarakat desa belum siap dan masih beradaptasi dengan sistem pertemuan virtual atau online. Transfer pengetahuan metode tatap muka virtual ini tergolong metode baru di tingkat desa. Setelah pelaksanaan penyuluhan pertama, dilakukan peningkatan motivasi melalui whatsapp group supaya masyarakat dapat mengikuti penyuluhan online kedua dan ketiga. Pada pertemuan kedua dan ketiga, peserta telah mencapai 27 orang sekitar $90 \%$ dari target peserta. Meningkatnya peserta penyuluhan online ini, dipandang ber-hasil mengedukasi masyarakat Desa Tirtomulyo untuk trampil mengikuti pertemuan online khususnya menggunakan ruang rapat virtual google meet.

Pendampingan masyarakat dilanjutkan melalui whatsapp group dengan nama grup Pemberdayaan Masyarakat Desa Tirtomulyo.

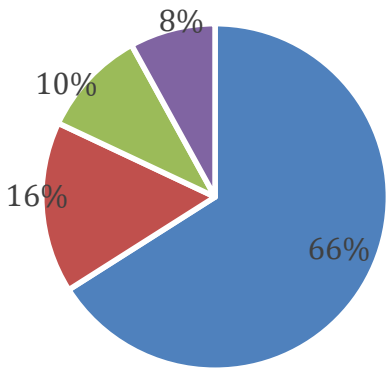

Gambar 6 Persentase pekarangan berdasar luas di Desa Tirtomulyo.

Tabel 2 Jenis tanaman pekarangan

\begin{tabular}{lcc}
\hline \multicolumn{1}{c}{ Jenis tanaman } & Jumlah & Persentase (\%) \\
\hline Tanaman sayuran & 30 & 31,91 \\
Tanaman buah & 44 & 46,81 \\
Tanaman herbal & 20 & 21,28 \\
Tanaman hias & 17 & 18,09 \\
Total & & 100,00 \\
\hline
\end{tabular}

Tabel 3 Elemen pekarangan selain tanaman

\begin{tabular}{lcc}
\hline $\begin{array}{c}\text { Elemen pekarangan } \\
\text { non tanaman }\end{array}$ & Jumlah & $\begin{array}{c}\text { Persentase } \\
(\%)\end{array}$ \\
\hline Kolam ikan & 14 & 48,28 \\
Gazebo & 4 & 13,79 \\
Bangku taman & 11 & 37,93 \\
Lainnya & 3 & 10,34 \\
Total & & 100,00 \\
\hline
\end{tabular}

Peserta diskusi merupakan perwakilan 15 dusun dan pamong desa. Diskusi online tersebut cukup aktif direspons perwakilan dusun dan desa, namun diskusi online tidak cukup menjamin pemahaman masyarakat desa dari topik yang sedang didiskusikan. Hanya orang tertentu saja yang merespons, masyarakat lain masih belum punya keberanian penuh untuk merespon. Upaya untuk memotivasi masyarakat terus dilakukan untuk meningkatkan respons masyakarat sehingga diskusi lebih interaktif. Suasana interaktif sangat diperlukan untuk mempercepat gerak dan untuk penilaian kapasitas masyarakat dalam upaya pemberdayaan masyarakat desa (Ruhiyat et al. 2020). Gambar 7 menunjukkan situasi interaksi online antar peserta dan narasumber dari UGM.

Penyuluhan daring atau online dirasakan oleh masyarakat tidak cukup untuk mendapatkan pemahaman optimal. Oleh karena itu, Kepala Desa Tirtomulyo mengundang seluruh perwakilan masyarakat untuk mempresentasikan identifikasi potensi dusun pada acara Sarasehan Desa. Berdasarkan apa yang mereka pelajari pada penyuluhan daring, perwakilan dusun membuat narasi minimal 500 kata untuk dinilai oleh 
pendamping UGM. Sarasehan desa dilaksanakan tanggal 17 September 2020 secara luring atau offline dengan protokol lesehatan ketat, yatu memakai masker, menjaga jarak, mencuci tangan dan dilarang berkerumun. Pada acara ini dipilih enam presentasi terbaik dan mendapat penghargaan oleh tim Desa Binaan UGM. Selanjutnya tiga dusun terbaik, yaitu Dusun Tluren, Genting, dan Jetis sebagai peserta dengan presentasi terbaik dan ditetapkan menjadi dusun penggerak desa. Pada Gambar 8 tampak masyarakat begitu antusias mempresentasikan potensi dusun masing-masing.

Selanjutnya pada tanggal 17 Oktober 2020 dilakukan pendampingan offline untuk meningkatkan kemampuan masyarakat dalam menyusun pengembangan agrowisata. Metode Business Model Canvas (BMC) dipilih karena cukup sederhana dan mudah dipahami masya- rakat serta disajikan dalam bentuk poster. Pendampingan dilakukan dengan metode TOT (training of trainer), dimana tiga dukuh terbaik pada acara Sarasehan Desa, yaitu Dusun Tluren, Genting dan Jetis menjadi koordinator tiga kelompok dengan anggota empat dusun per kelompok. Satu kelompok terdiri dari satu dusun koordinator penggerak desa dan empat dusun pendukung pembangunan. Diharapkan 15 dusun dapat memulai mengembangkan secara bersama-sama apa yang direncanakan untuk pengembangan agrowisata. Tiga dusun koordinator penggerak desa, Tluren, Genting, dan Jetis, membuat rencana pengembangan agrowisata dengan pendampingan tim UGM dengan metode BMC. Khususnya pada tiga koordinator dusun penggerak desa selalu diberi motivasi dan diskusi melalui whatsapp group "BMC Tirtomulyo". Hasil poster BMC disajikan pada Gambar 9.

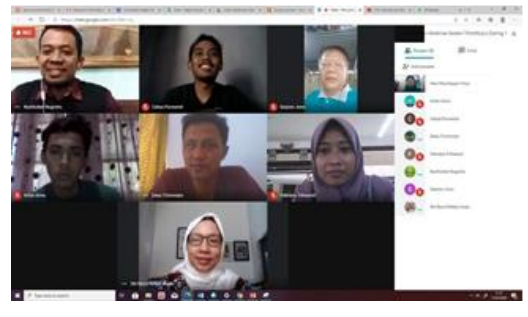

a

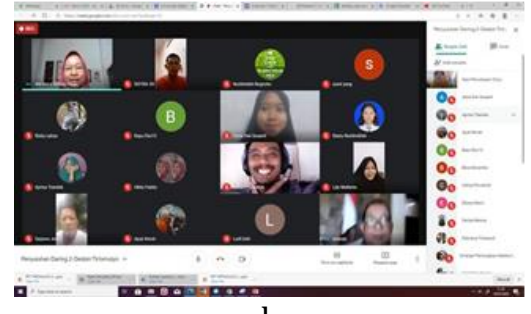

$\mathrm{b}$

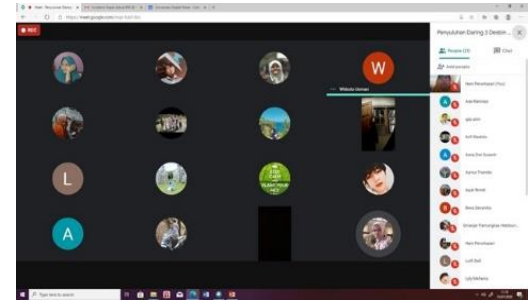

C

Gambar 7 Penyuluhan daring dengan masyarakat Tirtomulyo; a) Penyuluhan I, 11 Juli 2020; b) Penyuluhan II, 18 Juli 2020; dan c) Penyuluhan III, 25 Juli 2020.

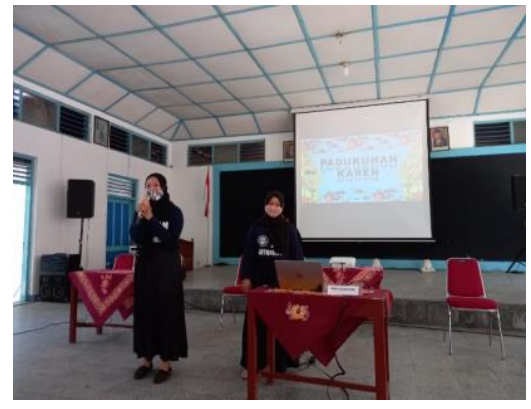

a

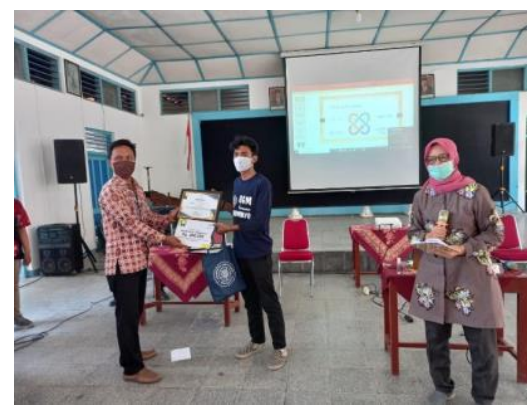

$\mathrm{b}$
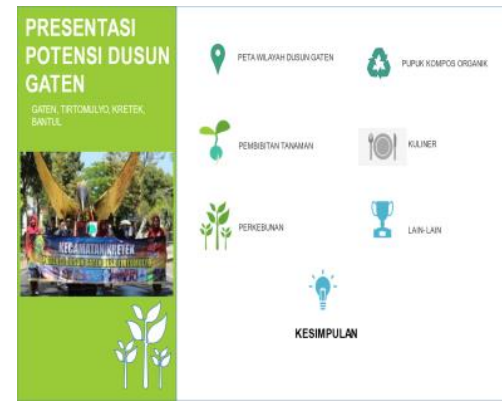

C

Gambar 8 Presentasi masyarakat, pemberian penghargaan kepada peserta terbaik dan contoh materi presentasi pada Sarasehan Desa.

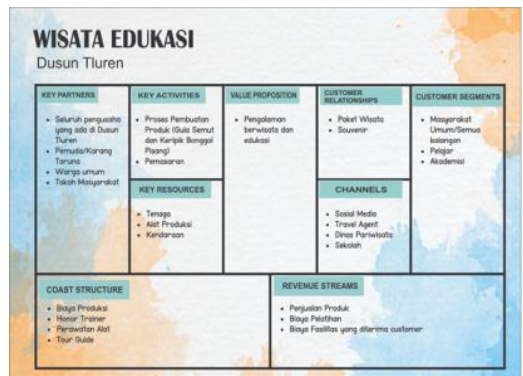

a

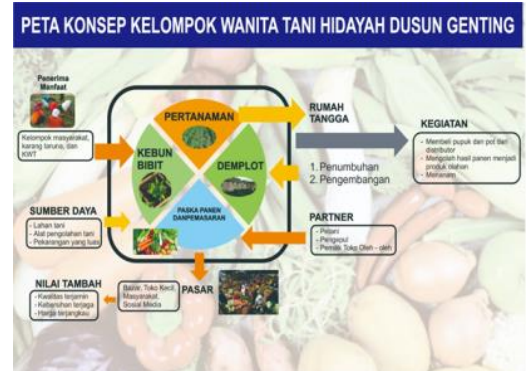

b

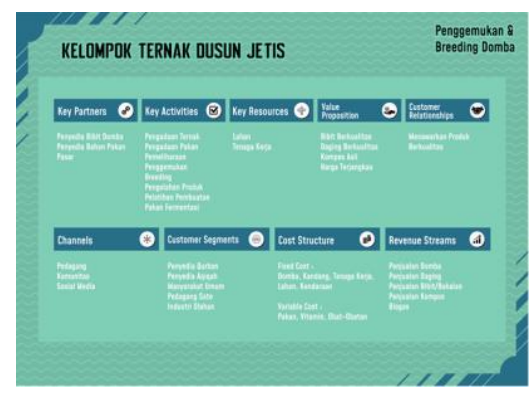

C

Gambar 9 Poster business model canvas Dusun Tluren, Genting, dan Jetis. 
Berdasarkan kapasitas masyarakat dalam mengembangkan kemandirian membangun desa di tahun pertama program Desa Binaan ini memberikan respons positif dan motivasi. Evaluasi hasil kerja BMS menunjukkan capaian sebagai berikut: 1) Dusun Tluren telah melakukan perencanaan secara runtut dan komprehensif, dengan catatan dapat ditambahkan gambar produk; 2) Dusun Genting, perencanaan sangat menarik, mudah dipahami, dan cukup komprehensif, dengan catatan masih belum ada partner untuk input usaha tani, segmentasi pasar, biaya dan sumber pendapatannya; dan 3) Dusun Jetis, perencanaan runtut dan komprehensif, dengan catatan customer relation dapat diisi promosi secara tidak langsung dan dapat ditambahkan gambar produk. Gambar 10 menunjukkan bentuk partisipasi aktf masyarakat melalui metode TOT. Tiga dusun penggerak sebagai koordinator kelompok melatih kembali dusun lain dalam penyusunan pengembangan agrowisata tahap awal di Desa Tirtomulyo. Diharapkan gerakan kelompok secara kolaboratif dengan kerja tim mampu mempersiapkan Desa Tirtomulyo menjadi desa agrowisata yang berefek pada peningkatan ekonomi masyarakat desa.

\section{SIMPULAN}

Program pengabdian kepada masyarakat berbasis Desa Binaan UGM pada tahun pertama 2020 menunjukkan partisipasi aktif dari masyarakat. Masyarakat dapat melakukan identifikasi potensi atraksi agrowisata di Desa Tirtomulyo dan berusaha untuk melakukan koordinasi di semua dusun di tingkat desa. Sebagian sumber daya alam telah diolah menjadi atraksi agrowisata, yaitu atraksi utama agrowisaata meliputi pekarangan, pertanian, perikanan, dan atraksi pendukung kerajinan tangan dan seni tari. Pemanfaatan sumber daya alam dan kapasitas masyarakat masih perlu ditingkatkan secara mandiri dan terkoordinasi di tingkat desa. Selanjutnya perencanaan agrowisata memerlukan penguatan kelembagaan dan master plan pariwisata.

\section{UCAPAN TERIMA KASIH}

Ucapan terima kasih diberikan kepada Direktorat Pengabdian kepada Masyarakat Universitas Gadjah Mada melalui hibah program

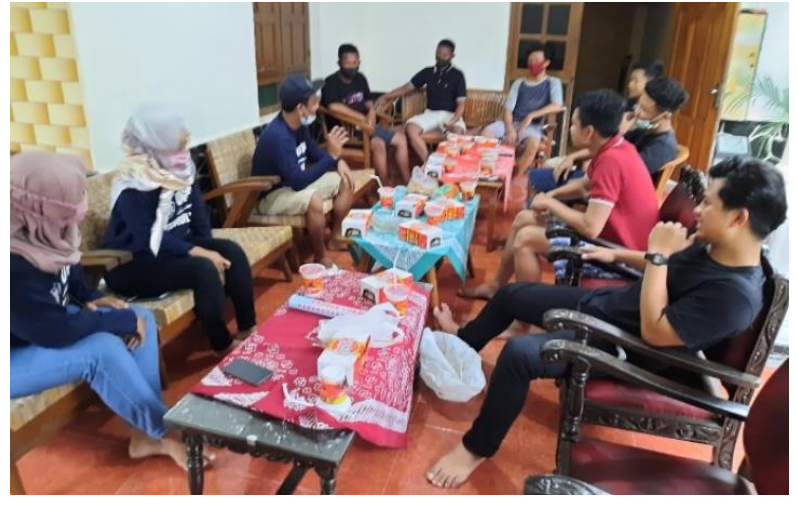

a

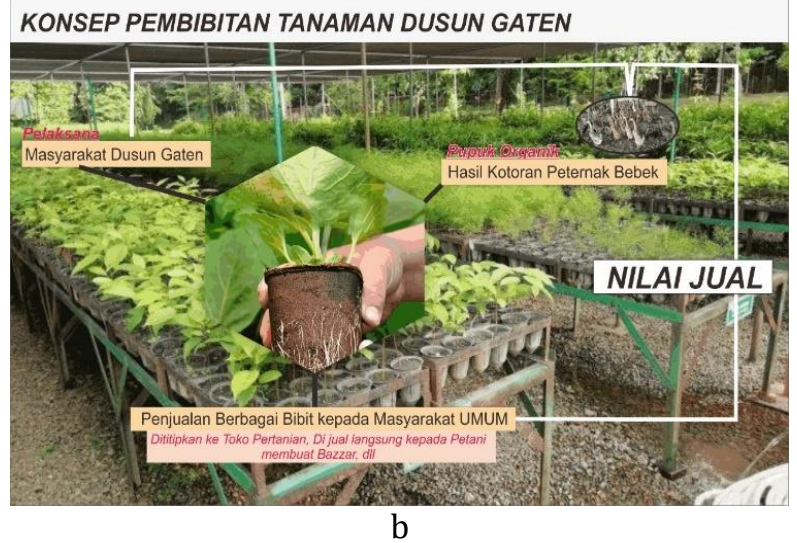

Gambar 10 a) Pelaksanaan pelatihan BMC oleh dusun penggerak sebagai koordinator kelompok dusun lainnya melalui metode TOT dan b) Poster BMC Dusun Gaten.

Desa Binaan 2020 sehingga masyarakat Desa Tirtomulyo menyambut baik dan program berjalan lancar. Ucapan terima kasih juga kepada tim Fakultas Pertanian dan Magister Kajian Pariwisata UGM serta perangkat Desa Tirtomulyo Bantul DIY atas dukungan untuk kelancaran program ini secara berkelanjutan.

\section{DAFTAR PUSTAKA}

Aristya GR, Aries BS, Lisna H, Agus S. 2017. Implementasi Inovasi Budi daya Stroberi di Agrowisata Banyuroto Kabupaten Magelang Melalui Education for Sustainable Development. Jurnal Pengabdian kepada Masyarakat. 2(2): 125-32. https://doi.org/ 10.22146/jpkm.26500

Balázsi Á, Dänhardt J, Collins S, Schweiger O, Settele J, Hartel T. 2021. Understanding cultural ecosystem services related to farmlands: Expert survey in Europe. Land Use Policy. 100(January 2019): 1-9. https://doi.org/10.1016/j.landusepol.2020.1 04900 
Batle J, Orfila-Sintes F, Moon CJ. 2018. Environmental management best practices: Towards social innovation. International Journal of Hospitality Management. 69(2017): 14-20. https://doi.org/10.1016/j.ijhm. 2017.10.013

Budi SP. 2015. Strategi pengembangan kawasan pariwisata perkotaan stdi kasus Jakarta. In: The ${ }^{2}$ nd University Research Colloquium. Page: 173-180.

Budiarti T, Suwarto, Muflikhati I. 2013. Pengembangan Agrowisata Berbasis Masyarakat Pada Usahatani Terpadu Guna Meningkatkan Kesejahteraan Petani dan Keberlanjutan Sistem Pertanian. Jurnal Ilmu Pertanian Indonesia. 18(3): 200-207.

Irwan SNR, Rogomulyo R, Trisnowati S. 2018. Pemanfaatan Pekarangan Melalui Pengembangan Lanskap Produktif di Desa Mangunan, Kabupaten Bantul Yogyakarta. Jurnal Ilmu Pertanian Indonesia, 23(2): 148157. https://doi.org/10.18343/jipi.23.2.148

Irwan SNR, Rogomulyo R, Suprihanto J, Hadi S. 2019. The Edutourism Of Mangunan Girirejo Yogyakarta: A Plan Strategy In Educational Innovation Of Universitas Gadjah Mada. Journal of Environmental Management and Tourism. 10(4): 892-902. https://doi.org/10.14505/jemt.v10.4(36).21

Keane SF, Cormican KT, Sheahan JN. 2018. Comparing how entrepreneurs and managers represent the elements of the business model canvas. Journal of Business Venturing Insights. 9(February): 65-74. https://doi.org/10. 1016/j.jbvi.2018.02.004

Putra AP, Amalia FR, Utami SW. 2018. Community Based Tourism di Desa Sumber Arum Kecamatan Songgon Banyuwangi. Dalam: Seminar Nasional Manajemen Dan Bisnis Ke-3 Program Studi Manajemen Fakultas Ekonomi Dan Bisnis Universitas Jember. Jember (ID). Page: 478-491

Ruhiyat R, Indrawati D, Indrawati E, Siami L. 2020. Upaya Pemberdayaan Masyarakat dalam Penerapan Sistem Pertanian Terpadu di Kampung Injeman, Desa Cibodas, Kecamatan Pasirjambu, Kabupaten Bandung. Agrokreatif Jurnal Ilmiah Pengabdian kepada Masyarakat. 6(2): 97-104. https://doi.org/ 10.29244/agrokreatif.6.2.97-105

Salvador R, Puglieri FN, Halog A, Andrade FGd, Piekarski CM, De Francisco AC. 2021. Key aspects for designing business models for a circular bioeconomy. Journal of Cleaner Production. 278(January): 1-14. https:// doi.org/10.1016/j.jclepro.2020.124341

Sesotyaningtyas M, Manaf A. 2015. Analysis of Sustainable Tourism Village Development at Kutoharjo Village, Kendal Regency of Central Java. Procedia - Social and Behavioral Sciences. 184(August 2014): 273-280. https://doi. org/10.1016/j.sbspro.2015.05.091

Lara SC, Crispin AF, Téllez MCL. 2018. Participatory rural appraisal as an educational tool to empower sustainable community processes. Journal of Cleaner Production. 172: 4254-4262. https://doi.org/10.1016/j. jclepro.2017.08.072

Tamam AB, Fahimah S. 2020. Pengembangan Agrowisata Berbasis Komunitas Melalui Program Edukasi Wisata dan Entrepreneurship Menuju Kemandirian Ekonomi Masyarakat. Engagement: Jurnal Pengabdian Kepada Masyarakat. 4(1): 100115. https://doi.org/10.29062/engagement. v4i1.139

Wisesa KA, Gunadi IAM, Mbulu YP. 2018. Creativity Based Tourism in Kampung Kreatif Dago Pojok Bandung. Journal of Tourism Destination and Attraction. 6(1) 15-24. https://doi.org/10.35814/tourism.v6i1.760

Wondirad A, Kebete Y, Li Y. 2021. Culinary tourism as a driver of regional economic development and socio-cultural revitalization: Evidence from Amhara National Regional State, Ethiopia. Journal of Destination Marketing and Management. 19(March): 1-15. https://doi.org/10.1016/j.jdmm.2020.10048 2 